\title{
PENGARUH JUS TOMAT TERHADAP PENURUNAN TEKANAN DARAH PADA PENDERITA HIPERTENSI LANSIA
}

\section{(THE EFFECT OF TOMATO JUICE TO DECREASE OF BLOOD PRESSURE ON HYPERTENSION PATIENTS)}

\author{
Nurul Hidayah $^{1 *}$, Agus Setyo Utomo ${ }^{2}$, Denys ${ }^{3}$ \\ ${ }^{1,2,3}$ Poltekkes Kemenkes Malang, Prodi Keperawatan Lawang \\ *e-mail:nh_150673@yahoo.com
}

\begin{abstract}
ABSTRAK
Mengatasi masalah hipertensi ada dua alternative yang bisa diberikan bagi penderita hipertensi yaitu dengan metode farmakologi maupun non farmakologis (secara tradisional). Penanganan farmakologi terdiri atas pemberian obat yang bersifat diuretik, penghambat saluran kalsium (ccb), betabloker, dan Penghambat ACE. Pengobatan non farmakologi salah satunya yaitu menggunakan Tomat. Tujuan penelitian adalah untuk mengetahui adanya perubahan tekanan darah pada penderita hipertensi yang mengonsumsi jus tomat di Kecamatan Lawang Kabupaten Malang pada 8-15 Juli 2016. Dengan metode penelitian Quasi eksperiment yang menggunakan pre test dan post test design. Populasi dalam penelitian ini adalah seluruh penderita hipertensi lansia yang belum pernah mengonsumsi jus tomat dan periksa rutin tekanan darah di Lawang yaitu sebanyak 30 orang. Dari hasil penelitian menunjukan bahwa nilai rata-rata tekanan darah awal 156/92 $\mathrm{mmH}$ dan rata-rata tekanan darah sesudah 142.33/88.52 $\mathrm{mmHg}$. Ada perubahan pemberian jus tomat terhadap penurunan tekanan darah sistolik dan diastolik. Sistolik sejumlah $5.33-1.00 \mathrm{mmHg}$ dan Diastolik sejumlah 1.64 - $0.33 \mathrm{mmHg}$. Perbedaan tekanan darah sebelum dan sesudah mengkonsumsi jus tomat pada responden yang diuji dengan Paired $\mathrm{T}$ Test. Hasil menunjukkan terjadi penurunan tekanan darah pada penderita hipertensi dengan nilai Pvalue $=0,000<a=0,05$. Hal ini menunjukkan ada pengaruh yang signifikan jus tomat terhadap penurunan tekanan darah pada penderita hipertensi dengan nilai $\mathrm{p}=0,000$. Hasil penelitian ini di dapat $\mathrm{p}$ value $0,00<$ 0,05 yang berarti $\mathrm{h}_{0}$ ditolak dikarenakan sig. (2-tailed) lebih kecil dari $\mathrm{a}$, artinya ada pengaruh setelah diberikan jus tomat terhadap tekanan darah penderita hipertensi.
\end{abstract}

Kata kunci: Hipertensi lansia, Jus Tomat, Tekanan Darah

\section{ABSTRACT}

Overcoming the problem of hypertension there are two alternatives that can be given for people with hypertension is by pharmacological and non-pharmacological methods (traditionally). Pharmacological treatments consist of diuretic medications, calcium channel inhibitors (ccb), betablenzers, and ACE inhibitors. Non pharmacology treatment one of them is using Tomato. The purpose of this study was to determine the presence of changes in blood pressure in hypertensive patients who consumed tomato juice in Lawang District Malang Regency on 8-15 July 2016. With quasi experimental research method using pre test and post test design. The population in this study is all elderly hypertensive patients who have never consumed tomato juice and check the blood pressure routine at Lawang that is as many as 30 people. From the results of the study showed that the average value of baseline blood pressure 156/92 $\mathrm{mmH}$ and average blood pressure after 142.33 / $88.52 \mathrm{mmHg}$. There is a change in the administration of tomato juice to decrease systolic and diastolic blood pressure. Systolic amount of $5.33-1.00 \mathrm{mmHg}$ and diastolic amount of $1.64-0.33 \mathrm{mmHg}$. Differences in blood pressure before and after consuming tomato juice on respondents tested with paired 
$T$ test. The results showed a decrease in blood pressure in patients with hypertension p-value value $=0,000<a=0.05$. This suggests that there is a significant effect of tomato juice on the decrease in blood pressure in hypertensive patients with a value of $p=0.000$. The results of this study can be p-value $0.00<0.05$ which means $\mathrm{HO}$ rejected due sig. (2-tailed) is smaller than a, meaning there is influence after being given tomato juice to blood pressure of hypertension patient.

Keywords: Elderly Hypertension, Tomato Juice, Blood Pressure

\section{PENDAHULUAN}

Kematian akibat penyakit hipertensi memang sering datang tiba-tiba. Sebagian kalangan pun menyebutkan sebagai The Silent Killer, "Pembunuh diam-diam". Gejala hipertensi sering tidak tampak dan penderitanya sering pula tidak merasa kesakitan sebelumnya. Oleh karena itu, banyak penderita hipertensi yang menyepelekannya (Meita, 2011).

Hipertensi atau tekanan darah tinggi adalah penyakit yang umum terjadi dalam masyarakat kita. Keadaan itu terjadi jika tekanan darah pada arteri utama di dalam tubuh terlalu tinggi. Hipertensi kini semakin sering dijumpai pada orang lanjut usia. Hipertensi merupakan kelainan yang sulit diketahui oleh tubuh kita sendiri. Satu-satunya cara untuk mengetahui hipertensi adalah dengan mengukur tekanan darah kita secara teratur. Tekanan darah tubuh yang normal adalah 120/80 (tekanan sistolik $120 \mathrm{mmHg}$ dan tekanan diastolik $80 \mathrm{mmHg}$ ). Namun, nilai tekanan darah tersebut tidak memiliki nilai yang baku. Hal itu berbeda-beda tergantung pada aktivitas fisik dan emosi seseorang (Meita, 2011).

Berikut ini adalah data statistika menggembirakan lainnya yang dikutip dari laporan JNC7. Bagi individu berusia 40-70 tahun. Peningkatan $20 \mathrm{mmHg}$ tekanan darah sistolik atau $10 \mathrm{mmHg}$ tekanan darah diastolik akan melipatgandakan resiko penyakit kardiovaskuler. Mari kita tinjau masalah ini secara lebih spesifik. Katakanlah, tekanan darah sistolik anda meningkat dari 115 menjadi 135 dalam periode waktu tertentu. Risiko anda telah meningkat sebanyak dua kali lipat. Dalam beberapa tahun, jika tekanan sistolik terus meningkat $20 \mathrm{mmHg}$ lagi hingga mencapai
155, resiko anda kembali bertambah dua kali lipat lagi (Kowaiski, 2010).

Berdasarkan data survey kesehatan rumah tangga (SKRT) pada 2000 menunjukkan bahwa kematian akibat penyakit jantung dan pembuluh darah di Indonesia sebesar 26,3\%. Sedangkan, berdasarkan data Rumah Sakit pada 2005 sebesar $16,7 \%$ kematian disebabkan hipertensi. Faktor resiko utama penyakit jantung dan pembuluh darah adalah hipertensi (Meita, 2011).

Besarnya angka kejadian hipertensi di dunia menurut Sutomo (2009) yang dilaporkan dari data Join National Commite On Pevention Detection Evaluation, And Treatment On High Blood Preassure 7, penderita hipertensi diseluruh dunia mendekati angka 1 miliar, hal ini bisa dikatakan 1 dari 4 orang dewasa menderita tekanan darah tinggi. Sekitar 600 juta penderita tersebar di beberapa negara berkembang. Hasil penelitian dari MONIKA (Multinatioal Monitoring Of Trends Determinants In Cardiovascular Diseases) angka kejadian di Indonesia berkisar 2-18\% diberbagai daerah. Jadi d Indonesia saat ini kira-kira terdapat 20 juta (Maya Apriyanti,2012).

Dan diketahui pada saat ini untuk mengatasi masalah hipertensi ada dua alternative yang bisa di berikan bagi penderita hipertensi yaitu dengan metode farmakologi maupun non farmakologis (secara tradisional). Penanganan farmakologi terdiri atas pemberian obat yang bersifat diuretik, penghambat saluran kalsium (ccb), betabloker, dan Penghambat ACE dengan memperhatikan tempat, mekanisme kerja dan tingkat kepatuhan. Dari pengobatan farmakologis terdapat beberapa efek samping. Efek 
samping tersebut bermacam-macam tergantung dari obat yang digunakan. Sebagai contoh, sakit kepala, kulit wajah memerah, dan pergelangan kaki membengkak ini merupakan efek samping dari penggunaan obat jenis CCB. Namun ternyata sejumlah orang berusaha menghindari penggunaannya mengingat adanya efek samping yang di timbulkan. Karena banyaknya efek yang di timbulkan oleh pengobatan secara farmakologi, maka masyarakat pada saat ini umumnya lebih memilih pengobatan secara non farmakologi, dikarenakan sedikitnya efek yang ditimbulkan dari pengobatan non farmakologis (Dr.Widharto, 2007).

Para Herbalis (Ahli herba) sangat yakin terhadap kemampuan herbal dalam mengobati berbagai penyakit, tanpa menimbulkan efek samping. Bahkan kemampuannya dapat disamakan dengan obat kimiawi. Jenis herba yang dapat dimanfaatkan untuk pengobatan hipertensi sebagai berikut, bawang putih (Allium Sativum), Bawang Merah (Alium Cepa). tomat (Lyocopercison lycopersicum), Seledri (Apium graveolens), Kumis kucing (Orthosiphon Stamineus) (Dr.Widharto, 2007).

Tomat

(Lyocopercison

lycopersicum). Merupakan salah satu dari jenis terapi herbal untuk menangani penyakit hipertensi. Tomat kaya akan kalium. Kerja kalium adalah mempengaruhi sistem renin angiotensin dengan menghambat pengeluaran. Renin yang bertugas mengubah angiotensinogen menjadi angiotensin I tetapi karena adanya blok pada sistem tersebut maka pembuluh darah mengalami vasodilatasi sehingga tekanan darah akan turun. Kalium juga menurunkan potensial membran pada dinding pembuluh darah sehingga terjadi relaksasi pada dinding pembuluh darah dan akhirnya menurunkan tekanan darah (Monika, 2013).

$$
\text { Raharjo (2012) melakukan }
$$
peneltian tentang pengaruh pemberian jus tomat terhadap tekanan darah sistolik dan diastolik pada penderita hipertensi.
Responden yang digunakan sebanyak 96 orang berumur 30-65 tahun di Wonorejo Lawang Kabupaten Malang. Responden diberikan jus tomat selama 7 hari sebanyak $250 \mathrm{ml}$ terbuat dari 150 gr tomat dan 100 $\mathrm{ml}$ air. Tujuan untuk mengetahui pengaruh jus tomat terhadap tekanan darah.

Lestari dan Rahayuningsih dalam Journal of Nutrition College (2012:414420) menjelaskan penelitian yang dilakukan di kota Semarang. Sebanyak 34 subyek penelitian wanita postmenopause diberikan jus tomat sebanyak $200 \mathrm{ml}$ terbuat dari 150 tomat, $5 \mathrm{~g}$ gula pasir dan $50 \mathrm{ml}$ air. Jus tomat diberikan satu kali selama 7 har berturut-turut. Hasilnya terdapat penurunan tekanan darah sistolik dan tekanan darah diastolik.

Jumlah penduduk Lawang keseluruhan berjumlah 8585 orang yang terdiri dari 4345 laki-laki dan 4240 perempuan. Penderita Hipertensi di Lawang dari semuanya berjumlah 30 orang yang rutin memeriksakan tekanan darahnya di Puskesmas.

Dari uraian di atas, maka peneliti tertarik untuk melakukan penelitian tentang pengaruh konsumsi jus tomat terhadap penurunan tekanan darah pada penderita hipertensi yang terjadi di Lawang Malang.

\section{METODE}

Dalam penelitian ini menggunakan metode Quasi eksperiment dengan pre test dan post test design. Populasi dalam penelitian ini adalah seluruh penderita hipertensi yang belum pernah mengonsumsi jus tomat dan periksa rutin tekanan darah sebanyak 30 orang.

Teknik sampling yang digunakan ialah sampling jenuh dengan kriteria inklusi:

1. Penderita Hipertensi sesuai kriteria WHO/ISH. yang belum pernah mengonsumsi jus tomat dan periksa rutin,

2. Penderita Hipertensi yang dapat menulis dan membaca. 
3. Bersedia menjadi responden penelitian dengan mengisi dan menandatangani informed consent.

Kriteria eksklusi meliputi: penderita hipertensi yang mengkonsumsi obat penurun tekanan darah.

Variabel dalam penelitian ini adalah perubahan tekanan darah pada penderita hipertensi yang mengonsumsi jus tomat dengan parameter: tekanan darah penderita hipertensi sebelum dan sesudah mengonsumsi jus tomat. Skala ordinal, dengan klasifikasi menurut WHO/ISH:

1. Normotensi $(<140 \mathrm{mmHg} /<90 \mathrm{mmHg})$

2. HT Ringan $(140-180 \mathrm{mmHg} / 90-$ $105 \mathrm{mmHg}$ )

3. HT Perbatasan $\quad(140-160 \mathrm{mmHg} / 90-$ 95mm Hg)

4. HT Sedang \& Berat $(>180 \mathrm{mmHg} />105 \mathrm{~mm} \mathrm{Hg})$

5. HT Sistolik terisolasi $(>140 \mathrm{mmHg} /<90 \mathrm{~mm} \mathrm{Hg})$

6. HT Sistolik Perbatasan (140$160 \mathrm{mmHg} /<90 \mathrm{~mm} \mathrm{Hg}$ )

Instrumen dalam penelitian ini menggunakan tensimeter untuk mengukur tekanan darah dan angket untuk mengisi biodata dan lembar observasi yang dibutuhkan. Penelitian dilaksanakan selama 7 hari.

\section{HASIL}

Karakeristik Responden Berdasarkan Kelompok Usia

Tabel 1. rata-rata responden berdasarkan kelompok usia

\begin{tabular}{llllc}
\hline Variabel & Mean & SD & $95 \%$ & CI \\
\hline Usia & 57.50 & 6.786 & 54.97 & -60.03 \\
\hline
\end{tabular}

Dari tabel tersebut dapat diketahui bahwa rata-rata usia responden adalah 57.50 Tahun (95\% CI : 54.97 - 60.03), dengan standart devisiasi 6.786 tahun. Usia termuda 46 tahun dan usia tertua 75 tahun. Dari hasil estimasi interval dapat disimpulkan bahwa diyakini rata-rata usia responden adalah diantara 54.97 sampai 60.03 tahun.

\section{Karekteristik Responden Berdasarkan Jenis Kelamin}

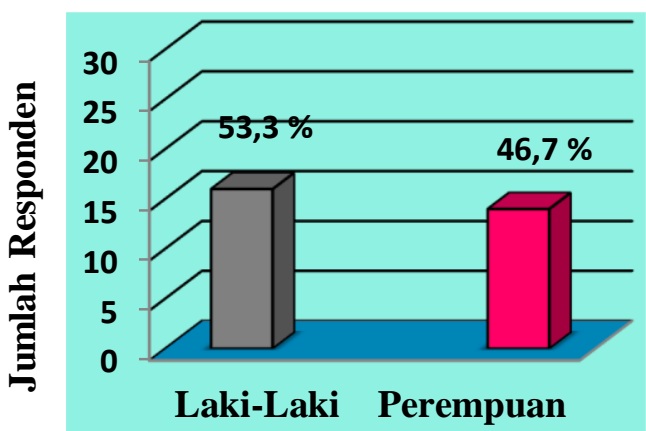

Jenis Kelamin

Gambar 1. Diagram Responden Berdasarkan Jenis kelamin.

Berdasarkan gambar diatas dari penelitian terhadap 30 responden diperoleh data tentang jenis kelamin dengan jumlah terbanyak adalah laki-laki sejumlah 16 responden dengan prosentase $53.3 \%$.

\section{Karakteristik Responden Berdasarkan Tekanan Sistolik}

Tabel 2. rata-rata responden berdasarkan tekanan darah sistolik.

\begin{tabular}{lllll}
\hline Variabel & Mean & SD & $95 \%$ CI & \\
\hline Sistolik & 153.67 & 14.259 & 158.99 & - \\
H+1 & & & 148.34 & \\
\hline Sistolik & 147.33 & 11.592 & 154.66 & - \\
H+2 & & & 146.00 & \\
\hline Sistolik & 146.67 & 11.121 & 153.49 & - \\
H+3 & & & 145.18 & \\
\hline Sistolik & 141.00 & 11.919 & 148.45 & - \\
H+4 & & & 139.55 & \\
\hline Sistolik & 137.33 & 12.959 & 145.84 & - \\
H+5 & & & 136.16 & \\
\hline Sistolik & 136.00 & 11.017 & 140.11 & - \\
H+6 & & & 131.89 & \\
\hline Sistolik & 134.33 & 11.351 & $138.57-$ & \\
H+7 & & & 130.09 & \\
\hline
\end{tabular}

Dari tabel 2 di atas dapat diketahui bahwa terdapat penurunan tekanan darah siastolik rata-rata responden $3.22 \mathrm{mmHg}$. 
Karakteristik Responden Berdasarkan Tekanan Diastolik

Tabel 3. rata-rata responden berdasarkan tekanan darah diastolik

\begin{tabular}{lcc}
\hline Variabel & \multicolumn{2}{c}{ Mea } \\
& $\mathrm{n}$ & SD 95\% CI \\
\hline $\begin{array}{l}\text { Diastolik } \\
\text { H+1 }\end{array}$ & 90.33 & $3.19891 .53-89.14$ \\
\hline $\begin{array}{l}\text { Diastolik } \\
\text { H+2 }\end{array}$ & 89.67 & $3.19890 .86-88.47$ \\
\hline $\begin{array}{l}\text { Diastolik } \\
\text { H+3 }\end{array}$ & 89.33 & $2.53790 .28-88.39$ \\
\hline $\begin{array}{l}\text { Diastolik } \\
\text { H+4 }\end{array}$ & 144.00 & $3.05190 .14-87.86$ \\
\hline $\begin{array}{l}\text { Diastolik } \\
\text { H+5 }\end{array}$ & 141.00 & $3.79089 .75-86.92$ \\
\hline $\begin{array}{l}\text { Diastolik } \\
\text { H+6 }\end{array}$ & 136.00 & $4.66188 .74-85.26$ \\
\hline $\begin{array}{l}\text { Diastolik } \\
\text { H+7 }\end{array}$ & 134.33 & $4.89387 .86-84.14$ \\
\hline
\end{tabular}

Dari table di atas dapat diketahui bahwa terdapat penurunan tekanan darah diastolik rata-rata responden $0.88 \mathrm{mmHg}$.

\section{Karakteristik Tekanan Darah Responden Sebelum Mengonsumsi Jus Tomat Berdasarkan Klasifikasi Tekanan Darah Sesuai WHO/ISH}

Tabel 4 Tekanan darah sebelum diberi perlakuan

\begin{tabular}{lcccc}
\hline Klasifikasi & \multicolumn{2}{c}{$\mathrm{n}$} & \multicolumn{2}{c}{$\%$} \\
\cline { 2 - 5 } \multicolumn{1}{c}{$\begin{array}{c}\text { Tekanan } \\
\text { Darah }\end{array}$} & $\begin{array}{c}\text { Seb } \\
\text { elu } \\
\text { m }\end{array}$ & $\begin{array}{c}\text { Sesu } \\
\text { dah }\end{array}$ & $\begin{array}{c}\text { Se } \\
\text { bel } \\
\text { um }\end{array}$ & $\begin{array}{c}\text { Sesud } \\
\text { ah }\end{array}$ \\
\hline Normotensi & - & 11 & & 36.67 \\
Hipertensi & 6 & 18 & 20 & 60 \\
Ringan & & & & \\
Hipertensi & 24 & - & 80 & \\
Perbatasan & & & & \\
Hipertensi & - & - & & \\
Sedang / & & & & \\
Ringan & & & & \\
Hipertensi & - & - & & \\
Sistolik & & & & \\
Terisolasi & & & &
\end{tabular}

\begin{tabular}{lll} 
Hipertensi & - & 1 \\
Sistolik & & \\
Perbatasan & & \\
\hline
\end{tabular}

Dari tabel 4 dapat diketahui bahwa dari 30 responden yang belum mengonsumsi jus tomat diperoleh data tentang tekanan darah dengan jumlah terbanyak adalah Hipertensi Perbatasan (140-160/90-95mmHg) yaitu 24 responden dengan prosentase $80 \%$. Dan sesudah mengonsumsi jus tomat dapat diketahui bahwa dari 30 responden diperoleh data tentang tekanan darah dengan jumlah terbanyak adalah Hipertensi Ringan (140$180 / 95-105 \mathrm{mmHg}$ ) yaitu 18 responden dengan prosentase $60 \%$.

Tabel 5. Hasil uji paired T-test pengaruh jus tomat terhadap hipertensi

\begin{tabular}{ccc}
\hline Kelompok & Mean & $\begin{array}{c}\text { Asymp.Sig. } \\
\text { (2-tailed) }\end{array}$ \\
\hline Pretest Jus Tomat & 295.00 &, 000 \\
\hline Postest Jus Tomat & 283.53 &, 000 \\
\hline
\end{tabular}

Dari table 5 didapatkan bahwa hasil penelitian terdapat pengaruh yang signifikan antara pre intervensi dan post intervensi karena nila $\mathrm{p}$-value $<0,05$.

\section{PEMBAHASAN}

Usia

Dari hasil penelitian didapatkan bahwa rata-rata usia responden adalah 57.50 Tahun (95\% CI : 54.97 - 60.03), dengan standar devisiasi 6.786 tahun. Usia termuda 46 tahun dan usia tertua 75 tahun. Dari hasil estimasi interval dapat disimpulkan bahwa diyakini rata-rata usia responden adalah diantara 54.97 sampai 60.03 tahun.

Bagi kebanyakan orang, tekanan darah meningkat seiring dengan bertambahnya usia. Bagi kaum pria, resiko ini lebih cepat terjadi, yaitu saat usia 45-50 tahun. Karena adanya hormone penyebab menstruasi, risiko hipertensi pada wanita dapat ditekan dan baru muncul 7-10 tahun 
setelah menopause. (Bebas hipertensi dengan terapi jus, 2005).

\section{Jenis Kelamin}

Berdasarkan gambar diatas dari penelitian terhadap 30 responden diperole data tentang jenis kelamin denan jumlah terbanyak adalah laki-laki sejumlah 16 responden dengan prosentase $53.3 \%$.

Menurut Dr. Suparyanto, M.Kes (2011) Hasil survey kesehatan rumah tangga tahun 1995 menunujukkan prevelensi penyakit hipetensi atau tekanan darah tinggi di Indonesia cukup tingg,yaitu 83 per 1000 anggota rumah tangga. Pada umumnya lebih banyak pria menderita Hipertensi dibandingkan dengan perempuan. Wanita $>$ pria pada usia $>50$ tahun, pria $>$ wanita pada usia $<50$ tahun.

Berdasarkan tabel 2 dan 3 dari penelitian terhadap 30 responden diperoleh data tentang tekanan darah sisitolik dan diastolik perhari selama 7 hari. Dari ratarata perhari ini kemudian dijadikan satu dan didapatkan hasil 142.33/88.52 mmHg terdapat perubahan tekanan darahsistolik maupun sistolik. Penurunan sistolik 6.34 $1.00 \mathrm{mmHg}$ dan penurunan diastolik 1.64 $0.33 \mathrm{mmHg}$.

Berdasarkan tabel 4.4 diatas dapat diketahui bahwa dari penelitian terhadap 30 responden diperoleh data tekanan darah sebelum mengonsumsi jus tomat dengan jumlah terbanyak adalah hipertesi perbatasan yaitu 24 responden dengan prosentase $80 \%$. Jumlah hipertensi ringan 6 responden $20 \%$.

Berdasarkan tabel 5 diatas dapat diketahui bahwa dari penelitian terhadap 30 orang responden diperoleh data tekanan darah sesudah mengonsumsi jus tomat dengan jumlah terbanyak adalah hipertensi ringan 18 orang denga prosentase $60 \%$. Jumlah normotensi 11 responden dengan prosentase $36.67 \%$. jumlah hipertensi sistolik perbatasan 1 responde dengan prosentase $3.33 \%$.

Penurunan tekanan darah sistolik dan diastolik pada penderita hipertensi karena kandungan kalium (potassium) yang terdapat pada tomat yang 147 mg/100gram atau 260 mol. Tomat mempunyai kemampuan membantu menurunkan tekanan darah karena kandungan kalium (potasium), lycopen, dalam buah tomat efektif dan mampu mengobati hipertensi. Selain itu, tomat juga bersifat diuretik karena kandungan asam yang tinggi sehingga membantu menurunkan tekanan darah. (Aphrodita,M. 2010) Sehingga kalium (potasium) membantu mengatur saraf perifer dan sentral yang mempengaruhi tekanan darah. Mengkonsumsi kalium yang banyak akan meningkatkan konsentrasinya di dalam cairan intraseluler sehingga cenderung menarik cairan dari bagian ekstraseluler dan menurunkan tekanan darah (Almatsier, 2001).

Tomat kaya akan kalium (235 mg/100 gr tomat), Kerja kalium dalam menurunkan tekanan darah adalah dapat menyebabkan vasodilatasi, sehingga terjadi penurunan retensi perifer dan meningkatkan curah jantung; kalium berfungsi sebagai diuretika, sehingga pengeluaran, natrium dan cairan akan meningkat, kalium menghambat pelepasan renin, sehingga mengubah aktifitas system renin angiotensin, kalium dapat mengatur saraf perifer dan sentral yang mempengaruhi tekanan darah. Tomat juga mengandung antioksidan yang kuat untuk menghambat penyerapan oksigen reaktif terhadap endotel yang mengganggu dilatasi pembulu darah, sehingga menyebabkan hipertensi. Tomat juga memiliki kandungan zat yang berkhasiat yaitu pigmen lycopene (berfungsi sebagai antioksidan yang melumpuhkan radikal bebas). Menyeimbangkan kadar kolesterol darah dan tekanan darah, serta melenturkan sel-sel saraf jantung yang kaku akibat endapan kolesterol dan gula darah), juga berguna untuk menurunkan tekanan darah.

Lestari dan Rahayuningsih dalam Journal of Nutrition College (2012:414420) menjelaskan penelitian yang dilakukan di kota Semarang. Sebanyak 34 subyek penelitian wanita postmenopause diberikan jus tomat sebanyak $200 \mathrm{ml}$ 
terbuat dari 150 tomat, $5 \mathrm{~g}$ gula pasir dan $50 \mathrm{ml}$ air. Jus tomat diberikan satu kali selama 7 har berturut-turut. Hasilnya terdapat penurunan tekanan darah sistolik sebesar 7.276 - $11.76 \mathrm{mmHg}$ dan tekanan darah diastolik3.321 - $8.82 \mathrm{mmHg}$.

Penurunan tekanan darah dapat dipengaruhi juga oleh usia. Sesuai dengan teori Elisa Diana Julianti,S.P. yang menyatakan bahwa Bagi kebanyakan orang, tekanan darah meningkat seiring dengan bertambahnya usia. Bagi kaum pria, resiko ini lebih cepat terjadi, yaitu saat usia 45-50 tahun. Hal ini didukung oleh hasil penelitian diatas tentang usia yang didapatkan sebanyak $100 \%$ berusia diatas 45 tahun. Hal ini berarti Hipertensi dapat dipengaruhi oleh pertambahan usia.

Penurunan tekanan darah dapat dipengaruhi juga oleh jenis kelamin. Sesuai dengan teori Dr. Suparyanto, M.Kes yang menyatakan bahwa Hasil survey kesehatan rumah tangga tahun 1995 menunujukkan prevelensi penyakit hipetensi atau tekanan darah tinggi di Indonesia cukup tingg,yaitu 83 per 1000 anggota rumah tangga. Pada umumnya lebih banyak pria menderita Hipertensi dibandingkan dengan perempuan. Hal ini didukung oleh hasil penelitian diatas tentang jenis kelamin yang didapatkan sebanyak $53.3 \%$ berjenis kelamin laki-laki. Hal ini berarti Hipertensi dapat dipengaruhi oleh jenis kelamin.

Menurut peneliti, hasil penelitian tentang perubahan tekanan darah pada penderita hipertensi yang mengkonsumsi jus tomat sesuai dengan teori diatas, yaitu penatalaksanaan untuk menurunkan tekanan darah pada penderita hipertensi dapat dilakukan salah satunya dengan mengkonsumsi jus tomat. Jus tomat dapat menurunka tekanan darah karena kandungan kalium (potasium), lycopen, dalam buah tomat efektif dan mampu mengobati hipertensi. Selain itu, tomat juga bersifat diuretik karena kandungan asam yang tinggi sehingga membantu menurunkan tekanan darah. Sehingga kalium (potasium) membantu mengatur saraf perifer dan sentral yang mempengaruhi tekanan darah. Mengkonsumsi kalium yang banyak akan meningkatkan konsentrasinya di dalam cairan intraseluler sehingga cenderung menarik cairan dari bagian ekstraseluler dan menurunkan tekanan darah. Inilah yang menyebabkan tekanan darah responden dengan perubahan tekanan darah pada penderita hipertensi yang mengkonsumsi jus tomat menurun.

\section{KESIMPULAN}

Ada pengaruh pemberian jus tomat dengan perubahan tekanan darah baik sistolik maupun diastolik.

1. Tekanan darah sistolik dan diastolik yang didapat sebagian besar responden sebelum mengonsumsi jus tomat adalah hipertensi perbatasan.

2. Tekanan darah yang didapat setelah mengonsumsi jus tomat mengalami perubahan yaitu tekanan darah sebagian besar responden menjadi hipertensi ringan dan normotensi.

3. Adanya pengaruh yang signifikan antara jus tomat terhadap tekanan darah hipertensi lansia di daerah Lawang

\section{SARAN}

Penelitian ini diharapkan akan dijadikan bahan pertimbangan dalam memberikan intervensi pengobatan hipertensi yang menggunkan bahan kimia dan dialihkan dengan menggunakan terapi jus tomat.

Dengan adanya penelitian bisa digunakan sebagai rujukan tentang teori pengobatan alternatif yang bersifat murah dan efisien dalam pelayanan kesehatan.

\section{KEPUSTAKAAN}

Lusia, K. 2011. “ Kolesterol Tinggi Picu Kematian Mendadak". Kompas.Com. Sabtu, 2 Juli 2011. Hlm. 1

Smeltzer, S. 2002. Buku Ajar Keperawatan Medikal Bedah Brunner Suddarth. Volume 2 Edisi 8. Jakarta : EGC 
Soeharto, I. 2004. Serangan Jantung dan Stoke Hubungannya Dengan Lemak dan Kolesterol. Jakarta: Gramedia Pustaka Utama

Wijayanti, D. Cara Mudah Mengatasi Problem Kolesterol. Yogyakarta: Bangkit

Anjarpratiwi, L. 2009. 100\% Hidup Sehat dan Panjang Umur dengan Terapi Jus. Jogjakarta : Araska

Apriyanti, M. 2013. Meracik Sendiri Obat \& Menu Sehat Bagi Penderita Darah Tinggi. Jogjakarta : Pustaka Baru Press

Arikunto, S. 2006. Prosedur Peneltian Suatu Pendekatan Praktik. Jakarta : Rineka Cipta

Corwin, EJ. 2009. Buku Saku Patofisiologi. Jakarta : Buku Kedokteran EGC

Kartikawati, E. 2012. Aneka Minuman Populer bagi Kesehatan. Ungaran : V-media

Kowaiski, R. 2010. Terapi Hipertensi. Bandung : Qonita

Kowal, J. 2011. Buku Ajar Patofisiologi. Jakarta : Buku Kedokteran EGC

Maharani, S. 2014. Herbal Sebagai Obat Bagi Penderita Penyakit Mematikan. Jogjakarta : A*Plus Books

Mansjoer, A. 1999. Kapita Selekta Kedokteran edisi 1. Jakarta : Media Aesculapius
Price, S \& Wilson. 2005. Patofisiologi Konsep Klinis Proses-proses Penyakit Edisi 6. Jakarta : Buku Kedokteran EGC

Sembiring, ME. 2013. Pemanfaatan Tomat terhadap wanita dewasa penderita Hipertensi tadium satu di RW 13 Kampung Mokla Bandung Barat. Univrsitas Advent Indonesia.

Shanty, M. 2011. Silent Killer Diseases Penyakit yang Diam-diam Mematikan. Jogjakarta : Javalitera

Soeria, A. 2014. 101 Resep Ampuh Sembuhkan Asam Urat, Hipertensi dan Obesitas. Jogjakarta : Araska

Sugiyono. 2010. Metode Penelitian Kuantitati Kualitatif dan R\&D. Bandung : Alfabeta

Sugiyono. 2010. Statistika Untuk Penelitian. Bandung : Alfabeta

Suparyanto. 2011. http://drsuparyanto.blogspot.com diakses pada tanggal 20 Desember 2014 pukul 10.00 WIB.

Widharto. 2007. Bahaya Hipertensi. Jakarta : Sunda Kelapa Pustaka.

www.cangcut.net/2013/02/khasiat-tomatuntuk-darah-tinggi. Diakses pada tanggal 03 Maret 2016 pada pukul 06.15 WIB.

www.wikipeda.org diakses pada tanggal 3 januari 2016 pada pukul 10.00 WIB 